\title{
Government Perception of Parepare Cities Towards Acceptance of Regional Financial Management Information System (SIPKD)
}

\author{
Gazali Muhammad $^{1}$, Mediaty $^{2}$, Asriani Hasan $^{3}$, Arini Yuniarty Buamona ${ }^{4}$, Anis Ansari ${ }^{5}$ \\ \{gazalimuhammad123@gmail.com¹, unhasmediaty@gmail.com², asriani.hasan@unismuh.ac.id ${ }^{3}$,
} arinyyuniarti@gmail.com ${ }^{4}$, anis.anshari177@gmail.com ${ }^{5}$ \}

Universitas Indonesia Timur ${ }^{1}$, Fakultas Ekonomi dan Bisnis Universitas Hasanuddin²,4,5

Universitas Muhammadiyah Makassar ${ }^{3}$

\begin{abstract}
Government and public sector organizations are expected to provide transparency and accountability of financial management to the public. This study aims to analyze user acceptance Fiscal Management Information System (SIPKD) in the city of Pare-pare. The survey method was used with questionnaires completed by 84 respondents and data users is analysis with AMOS. The results of this study indicate that: (1) perception of significant complexity to the perception of usefulness, but no significant effect on the use of technology; (2) perception of volunteerism affect significant to perceived ease, but no significant effect to use of technology; (3) perceptions of the usefulness and effect to use of technology; (4) perceived ease no significant effect on the use of technology; (5) experience as moderating variables significantly influence the perception of the usefulness in relationship to use of technology and significant relationship between perceived ease to use of technology with experience as moderating variable.
\end{abstract}

Keywords: Technology Acceptance Model, SIPKD, experience, complexity, voluntariness.

\section{Introduction}

The development of technology in the world at this time has reached a stage that is so fast, as is the case in Indonesia. The use of technology has entered various aspects, such as in the aspects of education, economic, social, government, entertainment, and even religion have also used technology. The government, as a public sector organization in using information systems, is expected to be able to provide transparency and accountability in financial management as accountability to the public. In the context of public accountability, local governments must conduct financial management in an economical, efficient, and effective manner (Value for Money) to improve the welfare of the community [1]. The implementation of information systems in government is an effort to realize good governance.

The Regional Financial Management Information System (SIPKD) is an application developed by the Ministry of Home Affairs in the context of accelerating data transfer and efficiency in collecting regional financial data. This is supported by the promulgation of Law Number 33 of 2004 concerning Financial Balance for the central government. Related to 
regional financial information has been regulated in PP no 56 of 2005 concerning regional financial information systems.

The implementation of SIPKD requires professional human resources. In addition, the experience is also needed in the application of SIPKD. The implementation of SIPKD forwarding has been carried out in the city of ParePare, which is in the Province of South Sulawesi. As is the case in other regions, SIPKD in the city of ParePare can also assist the regional government of ParePare in managing regional finances, starting from the budgeting process, administration, accounting, and reporting. It is thus helping to create transparency in the financial management of the city government of ParePare.

In previous studies, researchers have examined technology acceptance using TAM such as Davis Research (1989), regarding technology acceptance models, the interest in using technology can be predicted with perceived ease of use and perceived usefulness. Previous studies have also used experience a lot like an external variable [2].

Research that uses experience as an external variable includes Igbaria et al. (1995), Taylor \& Todd (1995), Szajna (1996), and Garder \& Amoroso (2004) [3]-[6]. Research Taylor \& Todd (1995) found a significant difference between experienced system users and users who have no experience in determining to use the system [7].

Research Gardner \& Amoroso (2004), experience (experience) is the second external variable used in research that affects the perceived usefulness (perceived usefulness) and behavioral (behavior) [6]. Jogiyanto (2007) mentioned in Ajzen \& Fishbein (1980) states, experience (experience) is also mentioned is a determinant of behavioral (behavior) [8]. Venkatesh \& Davis's research (2000), which developed TAM by incorporating two new constructs, namely social influence and cognitive instrumental processes, known as TAM2, uses experience (experience) as a moderating factor. The results are both significant constructs on technology acceptance [9].

This study modifies research from Gardner \& Amoroso (2004), which makes the experience as an external variable a moderating variable [6]. Research Gardner \& Amoroso (2004) states, examines internet technology for consumer organizations [6]. Like Gardner \& Amoroso (2004), TAM research is mostly conducted in the private sector, while this research is to look at technology acceptance in the public sector [6].

This study seeks to analyze the factors that influence the actual use of technology in the Regional Financial Management Information System (SIPKD) in the Regional Government of ParePare. The study was conducted at the Regional Government of ParePare City, which is within the scope of North Maluku Province.

This study aims to analyze the user acceptance of the Regional Financial Management Information System (SIPKD) of the city of ParePare by using the Technology Acceptance Model (TAM). Next, this study analyzes data to find out and explain the complexity of usefulness (perception of usefulness) in the use of Regional Financial Management Information Systems (SIKPD), knowing and explaining voluntariness variables towards perceived easy of use at ease. Use of Regional Financial Management Information System (SIKPD), knowing and explaining variable complexity (complexity), voluntariness (volunteerism), perceived usefulness (perceived usefulness), perceived ease of use (perceived ease) of actual use technology (use of real technology) in the system Regional Financial Management Information (SIKPD), knowing and explaining experience variables that moderate the relationship of perceived usefulness and perceived ease of use to actually use technology in the use of Regional Financial Management Information Systems (SIKPD). 


\section{Research Methodology}

\subsection{Location and Research Design}

The location of the study was conducted on 32 SKPD in the city of ParePare, South Sulawesi Province, by distributing questionnaires to the head of the finance department, treasurer, and financial staff. This research was conducted by taking a sample from a population using a questionnaire as a primary data collection tool to explain the causal relationship (cause and effect) between variables through hypothesis testing. The design of this research is explanatory research, which is research that combines several research variables that have been tested before. The data collection of this study used a survey design by giving questionnaires to respondents, namely the head of finance, treasurer, and financial staff who use SIPKD.

\subsection{Population and Sample}

The population in this study is SIPKD Users who are spread throughout the Regional Work Unit (SKPD) in the regional government of ParePare. The sample in this study was the head of finance, treasurer, and financial staff of each SKPD who used the SIPKD application.

\subsection{Method of Collecting Data}

The data used in this study uses primary data. Primary data is data collected through a questionnaire survey that is delivered and taken by the researcher himself. Validity test ( Table 1 ) is done by comparing the value of $r$ arithmetic with $r$ table for the degree of freedom (df) $=$ $\mathrm{n}-2$, in this case (n) is the number of samples. In this study the number of samples $(\mathrm{n})=84$ and the amount of $\mathrm{df}$ can be calculated 84-2 $=82$ with $\mathrm{df}=82$ and alpha $=0.05$ obtained $\mathrm{r}$ table $=$ 0.201 , the results obtained for all items have a positive value and $r$ count greater than $r$ table, then the items or questions or indicators in this study are declared valid. The reliability test (Table 2) obtained Cronbach's alpha value of $96.7 \%>0.7$, which, according to the criteria, can be said to be reliable.

The next, from the results of AMOS 18 processing according to appendix Table 3, the tstatistic value greater than 1.99 in 4.462 with a probability that is $0.00<0.05$, which means $\mathrm{H} 1 \mathrm{a}$ is accepted, the t-statistic value is smaller than 1.99 which is 1.725 with a probability of $0.084>0.05$ which means $\mathrm{H} 1 \mathrm{~b}$ is rejected, a t-statistic value greater than 1.99 in 5.523 with a probability of $0.00<0.05$ which means $\mathrm{H} 2 \mathrm{a}$ is accepted, a t-statistic value smaller than 1.99 namely 0.726 with a probability that is $0.468>0.05$ which means $\mathrm{H} 2 \mathrm{~b}$ is rejected. A t-statistic value greater than 1.99 is 3.567 with probability $0.00<0.05$, which means $\mathrm{H} 3$ is accepted, a tstatistic value smaller than 1.99 is 1.887 with a probability that is $0.061>0.05$ which means $\mathrm{H} 4$ is rejected. Hypothesis 5 can be seen in table 4 with a t-statistic value greater than 1.99 which is 5.844 with a probability that is $0.00<0.05$ which means $\mathrm{H} 5 \mathrm{a}$ is accepted, a t-statistic value greater than 1.99 which is 4.454 with a probability that is $0.00<0.05$ which means that $\mathrm{H} 5 \mathrm{~b}$ is received. 


\section{Result and Discussion}

This study shows in accordance with the results of testing hypothesis 1a that complexity has a significant effect on perceived usefulness. Based on the results of the study, it can be explained that the variable complexity (complexity) increases the perceived usefulness (perceived usefulness) in SIPKD users in the City of ParePare, South Sulawesi Province. These findings support research conducted by Igabria et al. (1996) and Gardner \& Amoroso (2004) that complexity has a positive relationship with perceived usefulness. Then hypothesis $1 \mathrm{~b}$ shows that the results of testing hypothesis $1 \mathrm{~b}$, which shows that complexity has a significant effect on actual use technology is not accepted [3], [6]. The higher the complexity of the SIPKD used, the lower the actual use technology seen from the user's perception. These findings support research conducted by Igabria et al. (1996) [3]. Research Thompson et al. (1991), which states the more complicated and innovation in information technology, the lower the level of acceptance of the innovation [10]. Research from Igbaria et al. (1995), which found there is a relationship between complexity (usage) and usage (actual use) [3].

Hypothesis 2 testing which states that the results of testing hypothesis $2 \mathrm{a}$ which shows that voluntariness has a significant effect on perceived easy of use is accepted. This means that the voluntariness variable increases the ease of use (perceived ease) of SIPKD users in ParePare City, South Sulawesi Province. These findings support research conducted by Sun \& Zhang (2003), that behavioral intentions vary between mandatory and voluntary system use. Then testing hypothesis $2 \mathrm{~b}$, which shows that voluntariness has a significant effect on use technology, is not accepted [11]. Based on the results of the study, it can be explained that the voluntariness variable does not significantly influence the actual use of technology in SIPKD users in the City of Pare-Pare, South Sulawesi Province.

Hypothesis 3 testing, which states that the results of perceived usefulness (perceived usefulness) significantly influence the actual use of technology, is accepted. Based on the results of the study, it can be explained that the variable perceived usefulness (perceived usefulness) increases the actual use of technology (use of actual technology) in SIPKD users in the City of ParePare, South Sulawesi Province. These findings support research conducted by Davis (1989), which states that perceived usefulness is a significant variable with usage [2].

Hypothesis testing 4, which states that the variable perceived ease of use has a significant effect on actual use technology, is not accepted. Based on the results of the study, it can be explained that the variable perceived ease of use does not significantly influence the actual use of technology in SIPKD users in the City of ParePare, South Sulawesi Province. Chau (1996) research supports the results of this finding, which states that perceived ease of use does not significantly influence the intention to use the system [12]

Hypothesis 5 testing, which states that the results of hypothesis testing 5a, which shows that there is a significant influence between perceived usefulness and actual use technology, which is moderated by experience, is accepted. This means that SIPKD users in ParePare City, South Sulawesi Province think that experience has to do with the benefits of technology acceptance. The more experienced the user is in using SIPKD-like technology, the easier it will be for users to accept and use SIPKD. These findings support research conducted by Szajna (1996) and Gardner \& Amoroso (2004) [5], [6]. Then testing hypothesis 5b, which shows that there is a significant influence between perceived ease of use and ease of use that is moderated by experience, is accepted. This finding shows that perceived ease of use, which is moderated by experience, has a significant effect on SIPKD acceptance. This means that 
experienced users will find SIPKD easy to operate compared to inexperienced users. These findings support the research of Igbaria et al. (1995), showing that experience will directly influence technology acceptance [3].

\section{Conclusion}

The results of the analysis and discussion described previously; it can be concluded that complexity has a significant effect on perceived usefulness but does not significantly influence the actual use of technology. Voluntariness has a significant effect on perceived ease of use but does not have a significant effect on actual use technology. Perceived usefulness has a significant effect on actual use technology, and the results still have a significant effect on being moderated with experience on actual use technology. Perceived ease of use does not have a significant effect on actual use technology but has a significant effect on actual use technology with experience as a moderating variable. Based on the conclusions above, it is recommended that further research be able to examine in depth about other factors that influence the use of SIPKD such as gender (gender) and complexity (complexity), and voluntariness (volunteerism) that become moderation variables.

\section{References}

[1] Herminingsih.: Pengaruh Partisipasi Anggaran dan Peran Manajerial Pengelolaan Keuangan Daerah Terhadap Kinerja Pemerintah Daerah (Studi Empiris pada Pemerintah Kabupaten Demak). Universitas Diponegoro: Semarang (2009).

[2] Davis. F.D.: Perceived usefulness, perceived ease of use, and user acceptance of information technology. MIS quarterly. pp. 319-340 (1989).

[3] Igbaria. M, Guimaraes. T, and Davis. G. B.: Testing the determinants of microcomputer usage via a structural equation model. Journal of management information systems. vol. 11, no. 4, pp. 87-114 (1995).

[4] Taylor. K.: Electrical conductivity. In Encyclopedia of Earth Sciences Series. (2009).

[5] Szajna. B.: Emperical Evaluation of the Revised Technology Acceptance Model. Management Science. vol. 42, no. 1, pp. 85-92 (1996).

[6] Gardner. C and Amoroso. S. L.: Development of an instrument to measure the acceptance of internet technology by consumers. In 37th Annual Hawaii International Conference on System Sciences (2004). Proceedings of the 2004, p. 10.

[7] Taylor. S and Todd. P.: Assessing IT Usage: the Role of Prior Experience. MIS Quarterly. pp. 561-570 (1995).

[8] Ajzen. I and Fishbein. M.: Understanding attitudes and predicting social behavior. Englewood Cliffs: Prentice-Hall (1980).

[9] Venkatesh. V and Davis. F. D.: A theoretical extension of the technology acceptance model: Four longitudinal field studies. Management science. vol. 46, no. 2, pp. 186-204 (2000).

[10] Thompson, L. Ronald, Haggings, A. Christoper, Howell, and Jane. M.: Personal Computing: Toward a Conceptual Model of Utilization. MisQuarterly. pp. 25-143 (1991).

[11] Sun. H and Zhang. P.; A New Perspective to Analyze User Technology Accaptance. Syracuse University (2003).

[12] Chau. P. Y. K. An empirical assessment of a modified technology acceptance model. Journal of management information systems. vol. 13, no. 2, pp. 185-204 (1996). 